\title{
Isolation and Partial Characterization of Melanoma-associated Antigens Identified by Autologous Antibody
}

\author{
Daniel R. Vlock, Deborah Scalise, Nancy Meglin, John M. Kirkwood, and Byron Ballou \\ Division of Medical Oncology, Pittsburgh Cancer Institute, University of Pittsburgh School of Medicine, \\ and Veterans Administration Medical Center, Pittsburgh, Pennsylvania 15240
}

\begin{abstract}
The study of the autologous immune response to cancer avoids the difficulties encountered in the use of xenoantisera and may identify antigens of physiological relevance. However, the low titer and incidence of autologous antibody to melanoma have hampered further evaluation. By utilizing acid dissociation and ultrafiltration of serum, we have been able to augment the detectable autologous immune response to melanoma in the majority of patients studied. In autologous system Y-Mel 84:420, serum $\mathrm{S} 150$ demonstrated a rise in titer from 1:32 in native sera to 1:262,044 after dissociation. The antigen detected by $\mathbf{S 1 5 0}$ was found to be broadly represented on melanoma, glioma, renal cell carcinoma, neuroblastoma, and head and neck carcinoma cell lines. It did not react with bladder or colon carcinoma, fetal fibroblasts, pooled platelets, lymphocytes and red blood cells, or autologous cultured lymphocytes. Using polyacrylamide gel electrophoresis, S150 detects a 66,000-mol wt antigen in spent tissue culture media and serum ultrafiltrate. In cell lysate two bands between 20,000 and 30,000 mol wt are detected by S150. The 66,000-mol wt antigen is sensitive to trypsin digestion and but is resistant to pepsin and heat inactivation. Exposure of spent media to trypsin results in the development of a 24,000 -mol wt band that appears to correspond to the antigen detected in the cell lysate. The difference between the antigens detected in the cell lysate as compared with spent media and serum ultrafiltrate may be due to degradation during cell lysis. We conclude that melanoma-associated antigens are present in the serum of patients with melanoma and are shed or secreted by their tumor cells.
\end{abstract}

\section{Introduction}

Numerous investigators have utilized a variety of antibody probes in the hopes of characterizing antigens that may distinguish melanoma and other tumors from their normal counterparts. The antibodies employed have been derived from polyclonal xenogeneic and allogeneic antisera (1-7) as well as murine and human monoclonal antibodies (8-14). Although these heterologous antibodies have been found to detect tumor-associated antigens, when sufficiently studied they have also been noted to react with normal cell constituents (15). Our investigations have focused upon the humeral immune

Address reprint requests to Dr. Vlock, Hematology/Oncology, VA Medical Center, University Drive C, Pittsburgh, PA 15240.

Received for publication 4 June 1987 and in revised form 19 October 1987.

J. Clin. Invest.

(c) The American Society for Clinical Investigation, Inc.

0021-9738/88/06/1746/06 \$2.00

Volume 81, June 1988, 1746-1751 response produced by the host. The advantage of studying autologous antibody reactivity is that it may detect antigens not apparent to heteroantisera. In addition, because the antibodies are produced by the host, they are directed against physiologically relevant antigens that may provide a better understanding of the role of the host-tumor interaction.

Antibody against autologous tumor cell surface antigens was first reported by Carey et al. $(16,17)$ and Shiku et al. $(18$, 19) using sensitive microserologic assays and cultured tumor cells. Antigens described in those studies were divided into three classes: those that are restricted to the tumor of a single individual (class I); those that are shared among tumors of a similar histotype or ontogeny and rarely, if ever, found in nonneoplastic cells (class II); and those that are found in nonneoplastic cells as well as tumors (class III). These authors showed antibody against autologous antigens in a third of melanoma patients studied-a finding confirmed in our investigations (20). However, the low incidence and weak titer of autologous antibody to melanoma have hampered continued investigation and has raised questions regarding the relevance of humeral immunity in melanoma.

We postulated that our failure to detect autologous antibody to melanoma with greater frequency may be due to the presence of circulating antigen forming immune complexes. To pursue this we modified a technique reported by Sjorgen et al. (21) to dissociate antibody from antigen in the sera of patients with melanoma. We have previously reported that this technique is successful in enhancing autologous antibody reactivity in 9 of 10 cases studied $(20,22)$. Serial studies of autologous antibody reactivity, in native and dissociated sera, have demonstrated correlations between clinical course and disease progression (22). In addition, we have found that the presence host-derived antibody reactivity against an allogeneic melanoma cell line is a predictor of eventual disease recurrence (23).

At present, the analysis of antigens detected by autologous antibody depends primarily upon determination of specificity in tests against a variety of malignant and nonmalignant cell lines. A more definitive approach is to characterize the antigen by immunochemical means. To date this has been difficult because of the low titer of antibody detectable in native sera and insufficient quantity of antigen. Only two successful immunochemical characterizations of class I melanoma antigens have been reported. Carey et al. (17) partially characterized a 25,000-40,000-mol wt class I antigen (AU) by gel filtration chromatography. More recently, Real et al. (24) reported a class I glycoprotein of $90,000 \mathrm{~mol} \mathrm{wt}$ isolated by immunoprecpitation with autologous antibody and radiolabeled melanoma cells.

Our ability to enhance autologous antibody titer by dissociation of immune complexes has allowed immunochemical analysis to proceed. We report the successful use of polyacrylamide gel electrophoresis (PAGE) with polyclonal autologous 
antibody in the detection of a class II melanoma antigen isolated from cell lysate, serum, and spent media.

\section{Methods}

\section{Cell lines}

Melanoma cells. Sterile tumor specimens were obtained, established, and maintained in a manner reported previously $(20,22)$. Melanoma lines Me 1447, Me 90, and Me 43 were kindly provided by Dr. Theresa Whiteside of the University of Pittsburgh School of Medicine, Pittsburgh, PA. Cultures established at three or more passages were used in serologic assays.

Nonmelanoma cells. Acquisition and maintenance of nonmelanoma cell lines have been previously reported (20). For specificity testing the following additional cell lines were used: glioma cell lines LN-18, GLL-19, and CL-105, neuroblastoma cell lines JMC-32 and SK-N-MC, and fetal fibroblast cell lines P-FF 86:100 and P-FF 86:110 supplied by Dr. Theresa Whiteside; renal cell carcinoma cell lines $5106 \mathrm{~W}, 630 \mathrm{D}, 531 \mathrm{~W}$, and IGR3 supplied by Dr. Byron Ballou; bladder carcinoma cell line HTB4 kindly provided by Dr. Craig McCune (University of Rochester, School of Medicine, Rochester, NY); and squamous cell carcinoma cell lines UMSCC 17A, 23, 35, and 36 provided by Dr. Thomas Carey (University of Michigan, School of Medicine, Ann Arbor, MI).

\section{Protein A hemadsorption}

The protein A hemadsorption assay was performed after the method described by Pfreundschuh et al. (25). Briefly, indicator cells for the protein A mixed hemadsorption tests were prepared by conjugating staphylococcal protein A (Pharmacia Fine Chemicals, Piscataway, NJ) to the surface of selected human blood group O- $\mathrm{Rh}^{+}$red blood cells with $0.01 \% \mathrm{CrCl}^{3}$ at $\mathrm{pH}$ 5.0. Indicator cells were washed twice in PBS plus $1 \%$ agamma FCS (Gibco, Grand Island, NY) and resuspended for use in this medium. Target monolayers were seeded in micro-Teresaki assay plates and reacted with serial dilutions of autologous sera. After incubation of target cells with sera at $37^{\circ} \mathrm{C}$, wells were washed three times with PBS containing $2 \%$ agammaglobulinemic FCS at $37^{\circ} \mathrm{C}$ and $0.01 \mathrm{ml}$ of an $0.15 \%$ suspension of indicator cells was added to each well. Plates were washed two to four times with PBS-2\% agamma FCS after $45 \mathrm{~min}$, and positive cells were read as follows: $(+)$ cells were those with a $>50 \%$ erythrocyte rosette. The end point of the assay was the last well with $10 \%$ of target cells $(+)$.

\section{Acid dissociation and ultrafiltration $(A D \& U)^{1}$}

The method, initially described by Sjogren et al. (21), was used to dissociate immune complexes. Briefly, a 60-ml ultrafiltration chamber and Amicon HP-30 membrane (Amicon Corp., Danvers, MA) were used. $2-3 \mathrm{ml}$ of prefiltered $(0.45 \mu \mathrm{m}$, Millipore Corp., Bedford, MA) serum was added to $50 \mathrm{ml}$ of glycine-saline buffer, $0.1 \mathrm{M}, \mathrm{pH} 3.1$, in the ultrafiltration chamber. Ultrafiltration was performed at $4^{\circ} \mathrm{C}$ under $10 \mathrm{psi}^{2}$ until the original volume of the test solution was reached. This process was repeated twice and then the serum was washed three times with $50 \mathrm{ml}$ of PBS, and concentrated to the original volume of serum. The total time involved varied from 24 to $48 \mathrm{~h}$ depending on the serum used.

\section{Absorption analysis}

Absorptions were performed using a wide range of fresh, cryopreserved, and cultured heterologous, allogeneic, and autologous cells (see Table I). These were washed three times and mixed at a 1:1 vol/vol (1 $\times 10^{8}$ cells $/ \mathrm{ml}$ minimum) with the serum to be tested $(0.1 \mathrm{ml}$, at a serum dilution two doublings above the endpoint of the titration for that serum). Absorptions were carried out for $30 \mathrm{~min}$ at $4^{\circ} \mathrm{C}$ and then $30 \mathrm{~min}$ at $37^{\circ} \mathrm{C}$. Specimens were then centrifuged at $2,000 \mathrm{rpm}$ for 20 min in a Sorvall RC3B refrigerated centrifuge (DuPont-Sorvall, New-

1. Abbreviations used in this paper: $\mathrm{AD} \& \mathrm{U}$, acid dissociation and ultrafiltration; NC, nitocellulose; TBS, Tris-buffered saline. town, CT). Supernatant serum was retested, with an aliquot of control unabsorbed serum incubated in parallel, using protein $A$ to assess the degree of specificity antibody absorption.

\section{Isolation of melanoma antigens}

Solubilization of melanoma cells. Preparation of melanoma antigens followed the method reported by Lloyd et al. (26). Briefly, cells from a confluent $150-\mathrm{cm}^{2}$ flask $\left(10^{7}\right.$ cells) were detached with EDTA and washed twice using PBS. $1.5 \mathrm{ml}$ of lysate buffer $(0.15 \mathrm{M} \mathrm{NaCl}, 0.01 \mathrm{M}$ Tris, $0.01 \mathrm{M} \mathrm{Mg} \mathrm{C12,1} \mathrm{mM}$ phenylmethysulfonyl fluoride, $2 \mathrm{U} / \mathrm{ml}$ aprotinin, $0.5 \% \mathrm{NP}-40, \mathrm{pH} 7.2$ ) was added to each $0.1 \mathrm{ml}$ of pellet. After incubating $15 \mathrm{~min}$ at $20^{\circ} \mathrm{C}$, the cells were spun at $100,000 \mathrm{~g}$ for $30 \mathrm{~min}$. The solution was clarified through a $0.22-\mu \mathrm{m}$ filter, aliquotted, and stored at $-70^{\circ} \mathrm{C}$.

Isolation of the ultrafiltrate from serum. The ultrafiltrate, obtained by acid dissociation and ultrafiltration, was concentrated by lyophilization. Preliminary work (22) and the absorption analysis illustrated in Fig. 1 has shown that this method allows for the preservation of antigenicity.

Isolation of antigen shed from autologous tumor cells. Spent autologous tumor cell media was obtained from a confluent $150-\mathrm{cm}^{2}$ flask. Media containing FCS were removed and the flask was washed twice with serum-free media, HB102 (New England Nuclear Research Products, Boston, MA). $50 \mathrm{ml}$ of serum-free media was added and incubated for $3 \mathrm{~d}$ at $37^{\circ} \mathrm{C}$. The viability of cells placed in serum-free media was $>95 \%$ at incubations of up to $5 \mathrm{~d}$. The media were then removed and concentrated $\times 20$ in an Amicon spinal fluid concentrator (Amicon Corp.).

PAGE of cell surface antigens extracted from SDS solubilized whole cells and eluted from acid-dissociated serum by ultrafiltration. One-dimensional SDS PAGE was performed after the method of Laemmeli (27). 10-cm gradient gels of 5-20\% acrylamide were made. Samples were dissolved in $0.025 \mathrm{M}$ Tris- $\mathrm{HCl}$ (pH 6.8), $2 \%$ SDS, $10 \%$ glycerol, $5 \%$ 2-mercaptoethanol with $0.001 \%$ bromphenol blue dye marker. Final sample volumes contained 5-10 $\mu \mathrm{g}$ of protein in $0.2-0.3 \mathrm{ml}$, and electrophoresis was carried out with a current of $20 \mathrm{~mA}$ until the bromphenol blue marker reached the margin of the gel.

Electrophoretic transfer of proteins from slab PAGE to nitrocellulose (NC). The methods of Towbin et al. (28) were used for transfer of proteins to a Hoefer transblot apparatus (Hoefer Scientific Instruments, San Francisco, CA). Transfer was performed at $40 \mathrm{~V}$ for $2-3 \mathrm{~h}$ (increased to $90 \mathrm{~V}$ during the last hour). The $\mathrm{NC}(0.2 \mu \mathrm{m}$, Scheicher \& Schuell, Inc., Keene, NH) to which electrophoretic transfer was accomplished was stained for protein with India ink (29) and immunologically.

Immune detection of transferred proteins. After transfer to NC, the sheet was air dried for $30 \mathrm{~min}$ at $20^{\circ} \mathrm{C}$ and then quenched in Tris-buf-

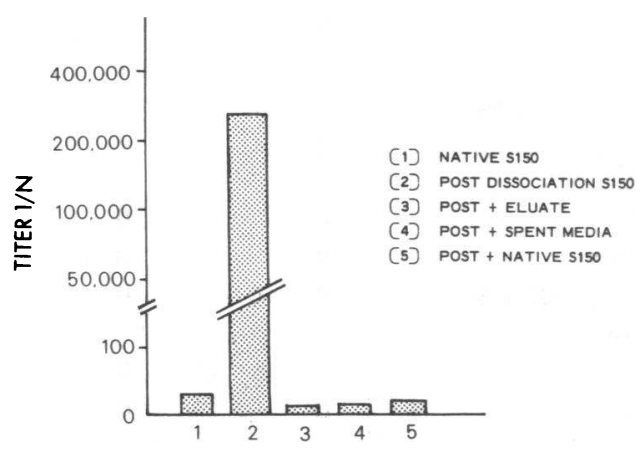

Figure 1. Absorption of autologous $\mathrm{S} 150$ reactivity. This illustrates the reactivity of serum $\mathrm{S} 150$ against autologous cultured melanoma Y-Mel 84:420. Native sera S150 (lane 1) gave a titer of 1:32. AD \& U sera S150 (lane 2) resulted in a titer of 1:262,044. The addition of an equal volume of autologous eluate obtained from ultrafiltration ablated enhanced reactivity (lane 3). A similar reduction in enhanced reactivity was seen with the addition equal volumes of autologous spent tumor culture media (lane 4) and native sera S150 (lane 5). 
fered saline (TBS) ph 7.5, plus $10 \%$ BSA for 45 min on a rocker. Antibody diluted in TBS in $0.05 \%$ Tween- 20 was overlaid on the NC paper and incubated on a rocker at $4^{\circ} \mathrm{C}$ for $16 \mathrm{~h}$. The paper was washed five times with TBS $+0.05 \%$ Tween- 20 for $5 \mathrm{~min}$. The second peroxidase-conjugated rabbit anti-human Ig antibody (Cappel Laboratories, Cochranville, PA), diluted with TBS plus $0.05 \%$ Tween 20 was overlaid on the NC paper and incubated at room temperature while rocking for $1 \mathrm{~h}$. After washing, the third antibody, peroxidase-conjugated goat anti-rabbit IgG (Cappel Laboratories) diluted in TBS plus $0.05 \%$ Tween 20 was overlaid on the NC paper and incubated while rocking at $20^{\circ}$ for $1 \mathrm{~h}$. The NC paper was developed with 4-chloro-1 naphthol in methanol $+30 \% \mathrm{H}_{2} \mathrm{O}_{2}$ for $15 \mathrm{~min}$. The reaction was stopped by removing the $\mathrm{NC}$ and placing it in a fresh container of $\mathrm{dH}_{2} \mathrm{O}$ and washing twice for $10 \mathrm{~min}$.

\section{Results}

Analysis of system Y-Mel 84:420. Before AD \& U, native serum Si 50 showed reactivity to a titer of 1:32 against autolo-

Table I. Serologic Definition of System Y-MEL 84:420 by Direct* and Absorption Analysis*

\begin{tabular}{|c|c|c|}
\hline Cell line & Direct & Absorption \\
\hline \multicolumn{3}{|l|}{ Melanoma } \\
\hline Y-MEL 84:420 & + & + \\
\hline Y-MEL 81:710 & + & + \\
\hline ME 1447 & + & + \\
\hline ME 90 & 0 & 0 \\
\hline ME 43 & 0 & 0 \\
\hline P-MEL 86:150 & + & + \\
\hline P-MEL 86:260 & + & + \\
\hline P-MEL 86:250 & + & + \\
\hline \multicolumn{3}{|l|}{ Glioma } \\
\hline LN 18 & 0 & 0 \\
\hline GLL 19 & + & + \\
\hline CL 105 & + & + \\
\hline \multicolumn{3}{|l|}{ Renal cell carcinoma } \\
\hline $5106 \mathrm{~W}$ & + & + \\
\hline 630D & + & + \\
\hline IGR3 & + & + \\
\hline $531 \mathrm{~W}$ & + & + \\
\hline Breast carcinoma, MCF 7 & 0 & + \\
\hline Bladder carcinoma, HTB4 & 0 & 0 \\
\hline \multicolumn{3}{|l|}{ Neuroblastoma } \\
\hline JMC 32 & 0 & + \\
\hline SK-N-MC & + & + \\
\hline \multicolumn{3}{|l|}{ Head and neck carcinoma } \\
\hline UMSCC 17A & + & + \\
\hline UMSCC 23 & + & + \\
\hline UMSCC 35 & 0 & 0 \\
\hline UMSCC 36 & 0 & 0 \\
\hline Colon carcinoma, HCT 8 & 0 & 0 \\
\hline \multicolumn{3}{|l|}{ Fetal fibroblasts } \\
\hline P-FF 86:100 & 0 & 0 \\
\hline P-FF 86:110 & 0 & 0 \\
\hline Autologous lymphocytes & & 0 \\
\hline Pooled platelets & & 0 \\
\hline Pooled lymphocytes & & 0 \\
\hline Pooled RBCs & & 0 \\
\hline Fetal calf serum & & 0 \\
\hline
\end{tabular}

* See Methods.

‡ Autologous tumor. gous melanoma cell line Y-Mel 84:420. After AD\&U, enhanced reactivity to $1: 262,044$ was noted, the highest titer yet reported in any autologous system (Fig. 1). As can be seen, enhanced autologous antibody reactivity could be ablated by the addition of autologous ultrafiltrate, native serum, and spent tumor culture medium. We have previously reported that sera from 10 normal individuals showed no reactivity against melanoma cells before or after AD\&U (20).

Specificity analysis of serum S150. Reactivity of serum S150 was tested by direct and absorption analysis against a variety of normal and malignant cell lines. The results are summarized in Table I. S150 was found to detect an antigen common to melanoma, glioblastoma, neuroblastoma, renal cell, head and neck, and breast carcinoma cell lines. It did not react with bladder and colon carcinoma, fetal fibroblasts, pooled lymphocytes, red blood cells and platelets, FCS, and cultured autologous lymphocytes.

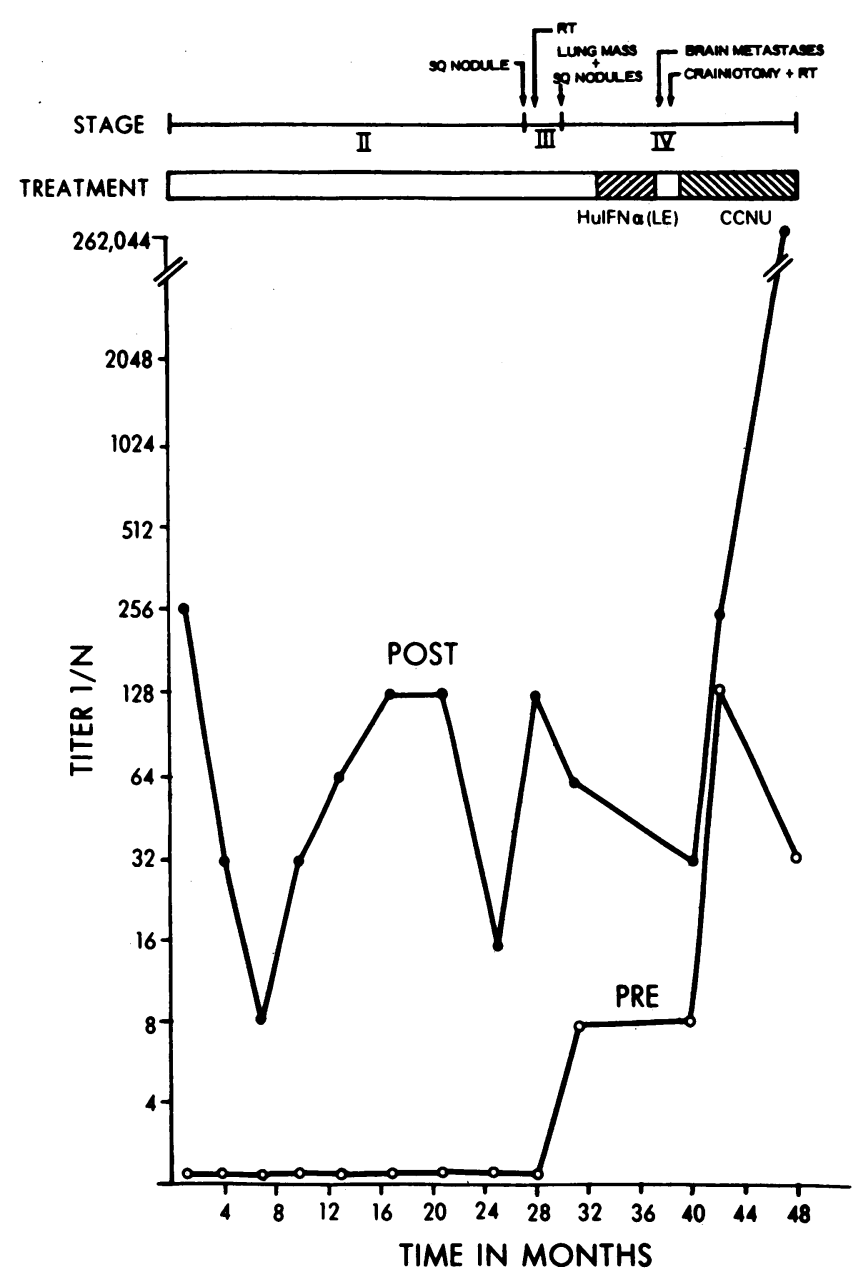

Figure 2. Serial autologous antibody titers Y-Mel 84:420. This is from a patient who initially presented with resected stage II melanoma and progressed onto metastatic disease. Sera obtained at several intervals were subjected to AD \& $U$ and tested against autologous melanoma by protein A hemadsorption. In dissociated sera (POST), antibody titer paralleled progression and recurrence of melanoma. The first two drops in dissociated antibody titer may have been due to resection of tumor. The last drop in dissociated antibody titer may be secondary to treatment with human leukocyte interferon $[H u I F N \alpha(L E)]$. Of note is a preterminal rise in both native (PRE) and dissociated antibody titers. CCNU, lomustine. 
Serial autologous studies of system Y-Mel 84:420. Sera obtained at 1-4-mo intervals were tested before and after AD\&U against autologous melanoma cells by protein A hemadsorption. The results were then correlated with clinical status and are illustrated in Fig. 2. In sera subjected to AD\&U (POST), antibody titer demonstrated a progressive rise that paralleled recurrence and progressive disease. The etiology of the first two drops is not clear but may be the result of treatment with surgery and radiotherapy, respectively. The third drop in antibody titer may be due to treatment with interferon as has been reported previously (22). Of additional note is the preterminal rise in both native (PRE) and AD\&U (POST) antibody titers. Serum obtained at month 48 was used for subsequent immunochemical analysis.

Immunochemical analysis. Cell lysate, spent media, and serum ultrafiltrate underwent PAGE and subsequent transfer to NC. Melanoma antigens were detected by immunoblotting with autologous dissociated serum S150. The results are illustrated in Fig. 3. As can be seen, autologous antibody detected a 66,000-mol wt antigen in serum ultrafiltrate and spent media (Fig. 3, strips $A 3$ and $B 3$ ). In the cell lysate, 2-3 bands between 20,000 and $30,000 \mathrm{MW}$ reacted with autologous serum (strips $C 2$ and $C 3$ ). Although other antigens were detected by autologous serum, they reacted with normal human sera as well. Normal human serum did not detect the 66,000 -mol wt antigen in serum ultrafiltrate or spent media (Fig. 3, strips $A 1$ and
B1). Nor did normal human serum react with the three 20,000-30,000-mol wt antigens found in the cell lysate (Fig. 3, strip $(1)$. In one experiment, antibody $\mathrm{S} 150$ was exposed to $10^{7}$ cells/ml of autologous melanoma Y-Mel 84:420 before immunoblotting. After absorption, S150 failed to detect the $66,000-\mathrm{mol}$ wt band while still reacting with the higher molecular weight antigen (Fig. 3, strip $D$ ).

Spent media was exposed to enzymatic digestion with pep$\sin (2,889 \mathrm{U} / \mathrm{ml}$, Millipore Corp.) and trypsin (1:250, Gibco) before immunoblotting (Fig. 4). The 66,000-mol wt antigen was lost by exposure to trypsin for $30 \mathrm{~min}$ (strip $C$ ). Exposure of spent media to pepsin for up to $5 \mathrm{~h}$ failed to ablate the antigen (strip $B$ ). Of note, exposure to trypsin resulted in the development of an additional band between 20,000 and 30,000 mol wt which appeared to correspond to the bands detected in the cell lysate. The antigen was not inactivated by heating to $100^{\circ} \mathrm{C}$ for $5 \mathrm{~min}$.

\section{Discussion}

This study reports the successful detection and partial purification of a class II melanoma antigen detected by autologous antibody. As shown in the specificity analysis performed, the antigen is represented on a wide number of neoplastic cells but not normal cells (see Table I). In addition, the antigen appears to be present on the cell surface and is readily shed in vitro and

\section{Y MEL 84:420}

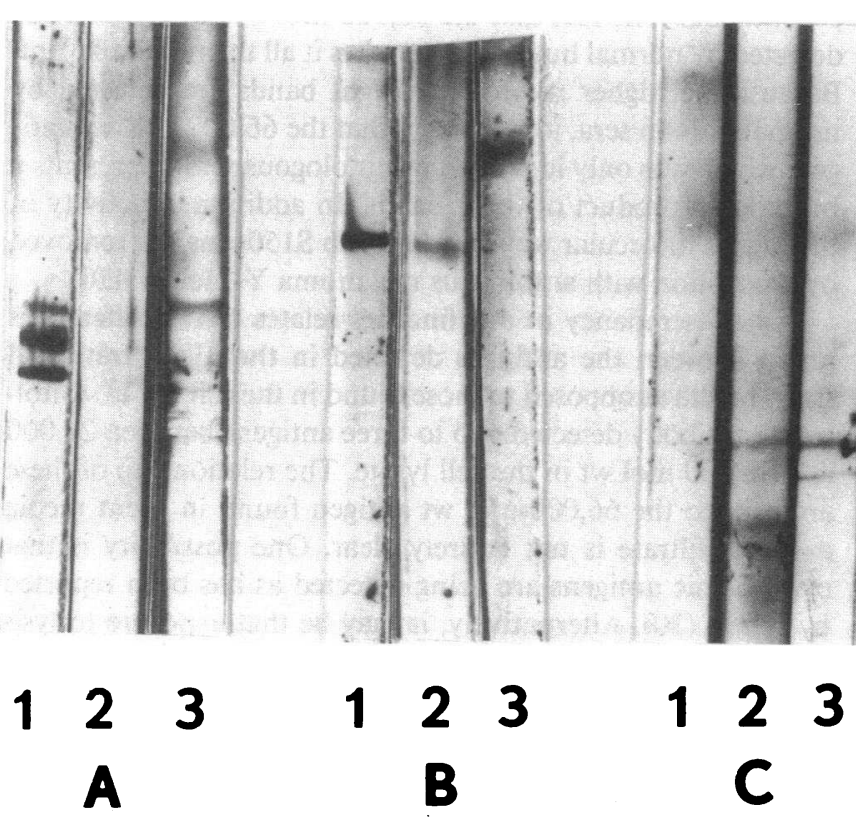

Figure 3. Immunoblots of melanoma antigens. Melanoma antigens isolated from ultrafiltrate $(A)$, spent media $(B)$, and cell lysate $(C)$ were subjected to PAGE, transferred to NC, and exposed to normal human sera (strips $A 1, B 1, C 1$ ), native autologous sera $\mathrm{S} 150$ (strips $A 2, B 2, C 2$ ), and dissociated autologous sera $\mathrm{S} 150$ (strips $A 3, B 3$, $C 3$ ). Dissociated autologous antibody detected a $66,000-\mathrm{mol}$ wt antigen in the ultrafiltrate and spent media ( $A 3$ and $B 3)$. In the cell lysate autologous sera $\mathrm{S} 150$ detected two to three bands between 20,000 and 30,000-mol wt (C2,C3). Normal human sera did not

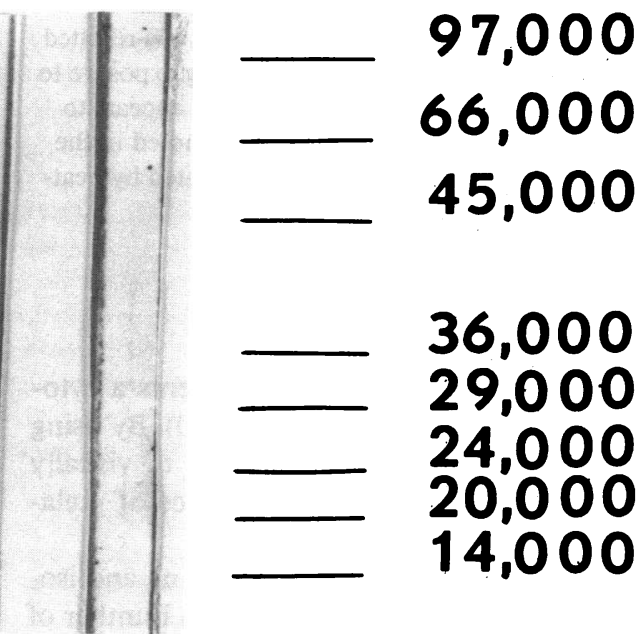

\section{D}

react with the $66,000-\mathrm{mol}$ wt antigen found by autologous antibody in the ultrafiltrate and spent media $(A 1, B I)$. Nor did normal human sera react with the $20,000-30,000-\mathrm{mol}$ wt antigens detected by autologous antibody on the cell lysate $(C l)$. (D) Absorption of autologous antibody reactivity. Before immunoblotting against spent media, antibody $\mathrm{S} 150$ was absorbed with $10^{7}$ cells $/ \mathrm{ml}$ of autologous melanoma Y-Mel 84:420. After absorption, S150 failed to detect the $66,000-\mathrm{mol}$ wt band while still reacting with the higher molecular weight antigen (strip $D$ ). 


\section{Y-MEL $84: 420$}

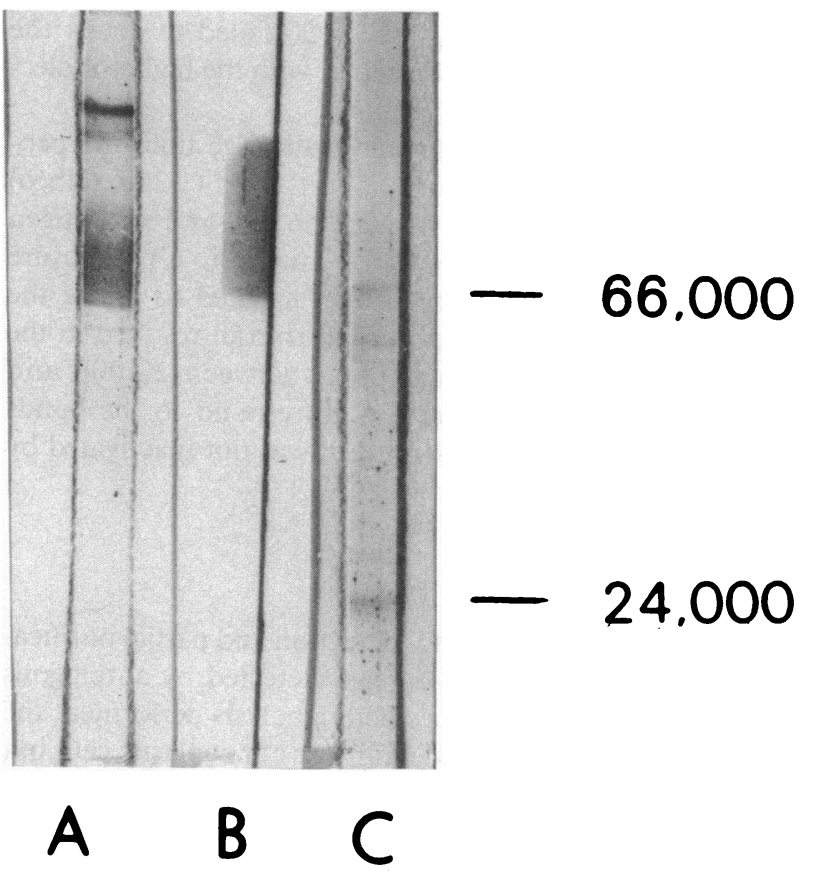

Figure 4. Enzymatic digestion of melanoma antigens. The excessive width of the 66,000 -mol $\mathrm{wt}$ band, due to overloading of the gel, was intentional in order to detect any breakdown products. Antigen obtained from spent media was exposed to trypsin and pepsin prior to PAGE and immunoblotting with dissociated autologous sera S150. With no enzymatic exposure $(A)$ the previously mentioned 66,000 $\mathrm{mol} \mathrm{wt}$ band is noted. Exposure to pepsin for $5 \mathrm{~h}(B)$ failed to destroy antigenicity, however a 30 -min exposure to trypsin $(C)$ resulted in loss of the antigen. Of additional note is that following exposure to trypsin the development of a 24,000 -mol wt band which appears to correspond to one of the lower molecular weight bands noted in the cell lysate (Fig. 3, strip C3). The antigen was not inactivated by heating to $100^{\circ} \mathrm{C}$ for $5 \mathrm{~min}$ (not shown).

in vivo (see Fig. 1). It is unlikely that this represents a cytoplasmic antigen as has been reported by others (30). By using the protein A hemadsorption assay, we are able to visually confirm the presence of the antigen on the surface of melanoma cells.

The difficulty encountered by others in detecting and isolating autologous antigens has been attributed to a number of factors: loss of antigen expression in vitro, poor immunogenicity of the antigens, antigenic heterogeneity, insufficient antibody levels, and the failure to immunoprecipitate the antigens $(17,24,31)$. This report and our previous studies $(20,22,23)$ would suggest an alternative explanation. We have found that the majority of patients with melanoma produce an antibody against their own tumor, however, it is masked by the presence of circulating antigen forming immune complexes. This would account for the low frequency and titer of autologous antibody in native serum and the problems encountered in antigen isolation. Our ability to significantly enhance antibody titer by acid dissociation and ultrafiltration has facilitated the isolation of autologous antigen. The autologous antibody titer of
1:262,044 found in dissociated serum S150 is over 100-fold higher than any previously reported.

The antigen isolated in these studies may be similar to the three class II melanoma antigens reported previously $(20,22)$. Comparisons between all four autologous systems reveals a similar range of reactivity. Pfreundschuh et al. (25) and Shiku et al. (19) noted cross-reactivity between the AJ astrocytoma antigen and the AH melanoma antigen although direct comparisons were never made. It is possible that our four autologous systems and those reported by others $(19,22,25)$ may be detecting a similar antigen. With the successful partial immunochemical purification of one autologous antigen, it is now possible to proceed with direct comparisons.

The 66,000-mol wt antigen that we have described has not previously been reported in autologous studies of human melanoma. It is doubtful that this antigen is similar to those detected by monoclonal antibodies (none of which have been $<90,000 \mathrm{~mol} \mathrm{wt}$ ) or the two previously reported autologous class I antigens. Although the antigens of similar molecular weight have been detected utilizing allogeneic and xenogeneic antibodies $(6,32)$, the distribution of these antigens on a wide variety of normal and xenogeneic tissues differs from what was noted in this study. In addition, because the antigen can be isolated by PAGE, it is unlikely that this antigen is similar to the gangliosides $G_{D 2}$ or $G_{M 2}$ which cannot be isolated by PAGE and are detected through the use of chloroform/methanol extraction and thin-layer chromatography $(31,33-35)$.

In addition to the 66,000 -mol wt antigen detected after PAGE, other bands were noted as well (Fig. 3). However, because these antigens were detected by normal human as well as autologous sera their significance is less clear cut. While antigens detected by allogeneic antibodies may be significant, previous studies $(6,32)$ have shown them to react with normal cell constituents. The fact that the $66,000-\mathrm{mol} \mathrm{wt}$ antigen was not detected by normal human sera makes it all the more relevant. Because the higher molecular weight bands are detected by normal human sera, it is unlikely that the 66,000-mol wt antigen, which was only identified by autologous sera, represents a breakdown product of those bands. In addition, reactivity of the higher molecular weight band with S150 was not removed by absorption with autologous melanoma Y-Mel 84:420.

One discrepancy in our findings relates to the differences noted between the antigens detected in the ultrafiltrate and spent media as opposed to those found in the cell lysate. Autologous antibody detected two to three antigens between 20,000 and $30,000 \mathrm{~mol} \mathrm{wt}$ in the cell lysate. The relationship of these antigens to the $66,000-\mathrm{mol}$ wt antigen found in spent media and ultrafiltrate is not entirely clear. One possibility is that cytoplasmic antigens are being detected as has been reported by others (30). Alternatively, it may be that exposure to lysis buffer and intracellular enzymes partially digested the antigen. Indirect evidence for this can be seen in our results in which exposure of spent media to trypsin resulted in the development of a $24,000-\mathrm{mol} w t$ band that appears to correspond to one of those seen in the cell lysate.

Further characterization of this autologous antigen is currently underway. Isolation of larger quantities of this antigen may allow the development of a more specific monoclonal antibody for the diagnosis and therapy of melanoma. Beyond that the ultimate goal of such studies will be to better understand the significance and biologic role of these antigens as they relate to the immune response and natural history of melanoma. 


\section{Acknowledgments}

The authors wish to thank Dr. Barry Solomon, vice president for research, W. R. Grace, Susan Hellier, and Saul M. Weiss, R. B. P. for technical advice and assistance.

This study was supported in part by grant CA-42922 from the National Cancer Institute. Dr. Vlock is a recipient of a Veterans Administration Career Development Award.

\section{References}

1. Chee, D. I., A. W. Boddie, and J. A. Roth. 1976. Production of melanoma-associated antigens by a defined malignant cell strain grown in chemically defined medium. Cancer Res. 36:1503-1509.

2. Roth, J. A., H. K. Slocum, M. A. Pellegrino, E. C. Holmes, and R. A. Reisfeld. 1976. Purification of soluble human melanoma-associated antigens. Cancer Res. 36:2360-2364.

3. Bystryn, J.-C., and J. R. Smalley. 1977. Identification and solubilization of iodinated cell surface melanoma associated antigens. Int. J. Cancer. 20:165-172.

4. McCabe, R. P., S. Ferrone, and M. A. Pellegrino. 1978. Purification and immunologic evaluation of human melanoma-associated antigens. J. Natl. Cancer Inst. 60:773-777.

5. Galloway, D. R., R. P. McCabe, M. A. Pellegrino, S. Ferrone, and R. A. Reisfeld. 1981. Tumor-associated antigens in spent medium of melanoma cells: immunochemical characterization with xenoantisera. J. Immunol. 126:62-66.

6. Heaney-Kieras, J., and J.-C. Bystryn. 1982. Identification and purification of a $75 \mathrm{~K}$ dalton cell-surface human melanoma associated antigen. Cancer Res. 42:2310-2316.

7. Vennegoor, C., P. Hageman, H. Van Nouhuijs, D. J. Ruitter, J. Calafat, P. J. Ringens, and P. Rümke. 1988. Am. J. Pathol. 130:179-192.

8. Koprowski, H., A. Steplewski, D. Herlyn, and M. Herlyn. 1978. Study of antibodies against human melanoma produced by somatic cell hybrids. Proc. Natl. Acad. Sci. USA. 75:3405-3409.

9. Yeh, M. Y., I. Hellstrom, J. P. Brown, G. A. Warner, J. A. Hansen, and K. E. Hellstrom. 1979. Cell surface antigens of human melanoma identified by monoclonal antibody. Proc. Natl. Acad. Sci. USA. 76:2927-2931.

10. Dippold, W. G., K. O. Lloyd, L. T. C. Li, H. Ikeda, H. F. Oettgen, and L. J. Old. 1980. Cell surface antigens of human malignant melanoma: definition of six antigenic systems with mouse monoclonal antibodies. Proc. Natl. Acad. Sci. USA. 77:2183-2187.

11. Woodbury, R. G., J. P. Brown, M-Y. Yeh, I. Hellstrom, and K. E. Hellstrom. 1980. Identification of a cell surface protein, p97 in human melanomas and certain other neoplasms. Proc. Natl. Acad. Sci. USA. 77:2183-2187.

12. Mitchell, K. F., J. P. Fuhrer, Z. Steplewski, and H. Koprowski. 1980. Biochemical characterization of human melanoma cell surfaces: dissection with monoclonal antibodies. Proc. Natl. Acad. Sci. USA. 77:7287-7291.

13. Harper, J. R., T. F. Bumol, and R. A. Reisfeld. 1984. Characterization of monoclonal antibody 155.8 and partial characterization of its proteoglycan antigen of human melanoma cells. J. Immunol. 132:2096-2104.

14. Bumol, T. F., and R. A. Reisfeld. 1979. Unique glycoproteinproteoglycan complex defined by monoclonal antibody on human melanoma cells. Proc. Natl. Acad. Sci. USA. 79:1245-1249.

15. Old, L. J. 1981. Cancer immunology: the search for specificity. G. H. A. Clowes memorial Lecture. Cancer Res. 41:361-375.

16. Carey, T. E., T. Takahashi, L. Resnick, and H. F. Oettgen. 1976. Cell surface antigens of human malignant melanoma. I. Mixed hemadsorption assays for humoral immunity to cultured autologous melanoma cells. Proc. Natl. Acad. Sci. USA. 73:3278-3282.

17. Carey, T. E., K. O. Lloyd, T. Takahashi, L. R. Travassos, and
L. J. Old. 1979. Cell-surface antigen of human malignant melanoma: solubilization and partial characterization. Proc. Natl. Acad. Sci. USA. 76:2898-2902.

18. Shiku, H., T. Takahaski, H. F. Oettgen, and L. J. Old. 1976. Cell surface antigens of human malignant melanoma. II. Serological typing with immune adherence assays and definition of two new surface antigens. J. Exp. Med. 144:873-881.

19. Shiku, H., T. Takahashi, L. Resnick, H. F. Oettgen, and L. J. Old. 1977. Cell surface antigens of human malignant melanoma. III. Recognition of auto-antibodies with unusual characteristics. J. Exp. Med. 145:784-789.

20. Kirkwood, J. M., and D. R. Vlock. 1984. Augmentation of autologous antibody to human melanoma following acid dissociation and ultrafiltration of serum. Cancer Res. 44:4177-4182.

21. Sjogren, H. O., I. Hellstrom, S. C. Bansal, and K. E. Hellstrom. 1971. Suggestive evidence that the "blocking antibodies" of tumorbearing individuals may be antigen-antibody complexes. Proc. Natl. Acad. Sci. USA. 68:1372-1375.

22. Vlock, D. R., and J. M. Kirkwood. 1985. Serial studies of autologous antibody reactivity to melanoma: relationship to clinical course and circulating immune complexes. J. Clin. Invest. 76:849854.

23. Vlock, D. R., R. DerSimonian, and J. M. Kirkwood. 1986. Prognostic role of antibody reactivity to melanoma. J. Clin. Invest. 77:1116-1121.

24. Real, F. X., J. M. Mattes, A. N. Houghton, H. F. Oettgen, K. O. Lloyd, and L. J. Old. 1984. Class I (unique) tumor antigens of human melanoma. identification of a 90,000 Dalton cell surface glycoprotein by autologous antibody. J. Exp. Med. 160:1219-1233.

25. Pfreundschuh, W., H. Shiku, T. Takahashi, R. Ueda, J. Ransohoff, H. F. Oettgen, and L. J. Old. 1978. Serological analysis of cell surface antigens of malignant human brain tumors. Proc. Natl. Acad. Sci. USA. 75:5122-5126.

26. Lloyd, K. O., N. G. Jennifer, and W. G. Dippold. 1981. Analysis of the biosynthesis of HLA-DR glycoproteins in human malignant melanoma cell lines. J. Immunol. 126:2408-2413.

27. Laemmeli, U. K. 1970. Cleavage of structural proteins during the assembly of the head of bacteriophage. Science (Wash. DC). 227:680-685.

28. Towbin, H., T. Staehelin, and J. Gordon. 1979. Electrophoretic transfer of proteins from polyacrylamide gels to nitrocellulose sheets: Procedures and some applications. Proc. Natl. Acad. Sci. USA. 76:4350-4354.

29. Hancock, J., and V. C. W. Tsang. 1985. India ink staining of proteins on nitrocellulose paper. Anal. Biochem. 133:157-162.

30. Mattes, J. M., T. M. Thompson, L. J. Old, and K. O. Lloyd. 1983. A pigmentation-associated, differentiation antigen of human melanoma defined by a precipitating antibody in human serum. Int. J. Cancer. 32:717-721.

31. Albino, A. P., K. O. Lloyd, A. N. Houghton, H. F. Oettgen, and L. J. Old. 1981. Heterogeneity in surface antigen and glycoprotein expression of cell lines derived from different melanoma metastases of the same patient. J. Exp. Med. 154:1764-1778.

32. Gupta, R. K., and D. L. Morton. 1983. Immunochemical characterization of fetal antigen isolated from spent medium of a human melanoma cell line. J. Natl. Cancer Inst. 70:993-1004.

33. Carubia, J. M., R. K. Tu, L. J. Macala, J. M. Kirkwood, and J. M. Varga. 1984. Gangliosides in normal neoplastic human melanocytes. Biochem. Biophys. Res. Commun. 120:500-504.

34. Tai, T., J. C. Paulson, L. D. Cahan, and R. F. Irie. 1983. Ganglioside GM2 as a human tumor antigen (OFA-I-1). Proc. Natl. Acad. Sci. USA. 80:5382-5396.

35. Irie, R. F., L. L. Sze, and R. E. Saxton. 1982. Human antibody to OFA-I, a tumor antigen, produced in vitro by Epstein-Barr virus transformed B-lymphoid cell lines. Proc. Natl. Acad. Sci. USA. 79:5666-5670. 